\title{
PENINGKATAN KAPASITAS MAHASISWI ANGKATAN 2019 PG PAUD FIP UNESA DALAM PEMBUATAN POWERPOINT KREATIF UNTUK ANAK
}

\author{
Sri Widayati ${ }^{1}$, Mallevi Agustin Ningrum ${ }^{1}$, Sri Setyowati ${ }^{1}$, Rohmatul Maulidiya ${ }^{1}$ \\ Pendidikan Guru PAUD, Fakultas Ilmu Pendidikan, Universitas Negeri Surabaya \\ Jalan Rektorat UNESA, Lidah Wetan, Kecamatan Lakarsantri, Kota Surabaya 60213 \\ Email Penulis Korespondensi: sriwidayati@unesa.ac.id
}

\begin{abstract}
Abstrak
Kurangnya pemahaman mahasiswi PG PAUD FIP Unesa angkatan 2019 mengenai pembuatan power point kreatif untuk anak usia dini dan keadaan saat ini terkait dengan adanya pandemiCOVID di Indonesia yang kian hari kiat meningkat menandakan masih kurangnya informasi yang di terima oleh masyarakat secara luas mengenai beragam informasi mengenai COVID. Selain itu proses kegiatan belajar mengajar merujuk pada Surat Edaran Mendikbud Nomor 3 Tahun 2020 tentang Pencegahan COVID-19 pada Satuan Pendidikan, dan Nomor 36962/MPK A/HK/2020 tentang pembelajaran secara daring dalam rangka pencegahan penyebaran Corona Virus Disease (COVID-19) membuat perlu diadakannya pelatihan pembuatan PowerPoint kreatif berbasis COVID-19 kepada mahasiswi PG PAUD angkatan 2019 FIP UNESA. Tujuan lain dari pelatihan ini akan membantu untuk menyebarluaskan informasi mengenai berbagai hal mengenai covid-19 terutama mengenai apa itu covid-19, bagaimana cara mencegah, apa saja yang dapat dilakukan oleh anak ketika berada di rumah. Serta meningkatkan pemahaman dan kemampuan mahasiswi untuk membuat power point yang sesuai dengan karakteristik anak (bentuk dan ukuran huruf, gambar, transisi, efek huruf dan gambar). Pelatihan berlangsung pada tanggal 29 April 2020 hingga 6 Mei 2020 dengan daring meneggunakan aplikasi WhatsApp. Metode yang digunakan dalam kegiatan pelatihan ini yaitu (1) diskusi; (2) tanya jawab; dan (3) pembimbingan PowerPoint secara langsung. Hasil pelatihan ini menunjukkan adanya peningkatkan pemahaman dan kemampuan mahasiswi dalam membuat power point kreatif yang sesuai untuk anak usia dini.
\end{abstract}

Kata Kunci : Power Point Kreatif, Covid-19, Mahasiswi PG PAUD

\begin{abstract}
The lack of understanding of PG PAUD FIP Unesa students in 2019 regarding the creation of creative power points for young children and the current situation related to the existence of the Covid pandemic in Indonesia which is increasingly increasing tips indicates that there is still a lack of information received by the public at large about a variety of information about COVID. Also Besides, the process of teaching and learning activities refer to the Minister of Education and Culture Circular Letter No. 3 of 2020 concerning Prevention of COVID-19 in Education Units, and Number 36962 / MPK A / HK / 2020 concerning Online Learning in the Context of Preventing Corona Virus Disease (COVID-19) make it necessary to hold training on making COVID-19-based creative power points for students of PG PAUD 2019 FIP Unesa. Another purpose of this training will help to disseminate information about various things about co-19, especially about what is co-19, how to prevent, what can be done by children when at home. And improve students' understanding and ability to make power points that are appropriate to the characteristics of the child (shape and size of letters, images, transitions, letter, and picture effects). The training took place on April 29, 2020, until May 6, 2020, with online using the WhatsApp application. The methods used in this training activity
\end{abstract}


are (1) Discussion; (2) question and answer; and (3) direct PowerPoint guidance. The results of this training show there is an increase in students' understanding and ability to create creative power points that are suitable for early childhood.

Keywords: Creative Power Point, COVID-19, PG PAUD Students

\section{PENDAHULUAN}

Pandemi COVID-19 berarti terjadinya wabah suatu penyakit COVID-19 yang menyerang banyak korban, serempak di berbagai negara. Sementara dalam kasus COVID-19, badan kesehatan dunia WHO menetapkan penyakit ini sebagai pandemi sejak Maret 2020 karena seluruh warga dunia berpotensi terkena infeksi penyakit COVID19. Penyakit ini telah memengaruhi banyak negara di dunia, salah satunya Indonesia. Kasus positif corona di Indonsia yaitu pada awal maret. Dalam rangka pencegahan COVID-19 ini pada 22 Maret Melalui Surat Edaran Mendikbud nomor 4 tahun 2020 mengimbau untuk melakukan pembelajaran daring atau pembelajaran jarak jauh.

Mendikbud menjelaskan aturan tentang poin-poin pembelajaran jarak jauh yaitu proses belajar dari rumah dilaksanakan dengan ketentuan bahwa belajar dari rumah melalui pembelajaran jarak jauh dilaksanakan untuk memberikan pengalaman belajar yang bermakna bagi siswa, tanpa terbebani tuntutan menuntaskan seluruh capaian kurikulum untuk kenaikan kelas maupun kelulusan, belajar dari rumah dapat difokuskan pada pendidikan kecakapan hidup antara lain mengenai pandemi COVID-19, aktivitas dan tugas pembelajaran belajar dari rumah dapat bervariasi sesuai minat dan kondisi masing-masing, termasuk mempertimbangkan kesenjangan akses atau fasilitas belajar di rumah dan bukti atau produk aktivitas belajar dari rumah diberi umpan balik yang bersifat kualitatif dan berguna dari guru, tanpa diharuskan memberi skor atau nilai kuantitatif.

Pada masa pademi COVID-19 anak usia dini juga termasuk individu yang melakukan pembelajaran di rumah. Dalam pembelajaran di rumah saja tentu anak usia dini membutuhkan media yang menarik dengan topik yang sesuai keadaan saat ini yaitu tentang COVID-19. Salah satu media yang dapat digunakan untuk memberikan informasi terhadap anak usia dini yaitu PowerPoint kreatif.

Microsoft PowerPoint merupakan salah satu produk unggulan Microsoft Corporation dalam program aplikasi persentasi yang paling banyak digunakan saat ini. Hal ini dikarenakan banyak kelebihan di dalamnya dengan kemudahan yang disediakan. Microsoft PowerPoint dapat merancang dan membuat presentasi yang lebih menarik dan profesional. Media PowerPoint merupakan media yang akan membantu dalam menyusun sebuah persentasi yang efektif, profesional, dan mudah yang menjadikan sebuah gagasan menjadi lebih menarik dan jelas tujuannya (Istiningsih, 2012: 119).

Pemanfaatan media persentasi ini dapat digunakan oleh pendidik maupun peserta didik untuk mempresentasikan materi pembelajaran atau tugas-tugas yang akan diberikan. Oleh sebab itu dalam memberikan pengetahuan tentang COVID-19 dalam pelatihan ini membuat media berupa powerpoint dengan berbagai slide dengan menampilkan gambar yang telah didesain sesuai dengan tujuan pembelajaran. Dengan menggunakan media dapat memperjelas penjelasan yang diberikan oleh pendisik atau calon pendidik kepada anak.

Dengan pemanfaatan media pembelajaran PowerPoint ini, ada beberapa hal yang menarik untuk digunakan sebagai media pembelajaran yaitu dapat menyajikan dengan berbagai macam huruf, warna, gambar dan animasianimasi yang dapat diolah sendiri dengan lebih kreatif dan dapat disesuaikan dengan kebutuhan pembelajaran. Sehingga proses pembelajaran menjadi lebih menarik.

Berdasarkan uraian diatas maka mahasiswi angkatan 2019 PG PAUD FIP UNESAdirasa perlu memiliki kemampuan dalam pembuatan media untuk anak usia dini. Sehingga mahasiswi PG PAUD perlu mendapat pelatihan membuat PowerPoint kreatif tentang COVID19 yang sesuai untuk anak usia dini. sehingga dilakukannya "Pelatihan Pembuatan PowerPoint Kreatif Berbasis COVID-19 Pada 
Mahasiswi Angkatan 2019 PG PAUD Fakultas Ilmu Pendidikan Universitas Negeri Surabaya" dengan tujuan untuk meningkatkan pemahaman dan kemampuan mahasiswi untuk membuat PowerPoint yang sesuai dengan karakteristik anak

\section{Analisa Situasi}

Indonesia termasuk salah satu negara di dunia yang mengalami pandemi COVID-19. Pemerintah Indonesia melakukan pembatasan sosial dengan cara melarang adanya kerumunan dalam masyarakat untuk menghindari penyebaran virus corona yang semakin meluas. Pada tanggal 22 Maret 2020 Kemendikbud mengeluarkan kebijakan belajar di masa pandemi ini dimana "Proses Kegiatan Belajar Mengajar merujuk pada Surat Edaran Mendikbud Nomor 3 Tahun 2020 tentang Pencegahan COVID-19 pada Satuan Pendidikan, dan Nomor 36962/MPK A/HK/2020 tentang pembelajaran secara Daring dan Bekerja dari Rumah dalam Rangka Pencegahan Penyebaran Corona Virus Disease (COVID-19), serta Surat Edaran dan petunjuk dari Kepala Daerah, dan Rektorat masingmasih Universitas". Dari beberapa kebijakan tersebut maka seluruh jenjang pendidikan mulai dari TK hingga Universitas melakukan pembelajaran secara daring.

Berhubungan dengan SE Dirjen Dikti dari laman resmi Kemendikbud, Rabu (5/4/2020), ada 5 (lima) ketentuan yang disampaikan, yakni 1. Masa belajar paling lama bagi mahasiswi yang seharusnya berakhir pada semester genap 2019/2020 dapat diperpanjang 1 (satu) semester, dan pengaturannya diserahkan kepada Pimpinan Perguruan Tinggi sesuai dengan kondisi dan situasi setempat. 2. Praktikum laboratorium dan praktik lapangan dapat dijadwalkan ulang sesuai dengan status dan kondisi di daerah. 3. Pengabdian tugas akhir selama masa darurat ini agar diatur, baik metode maupun jadwalnya, disesuaikan dengan status dan kondisi setempat. 4. Periode penyelenggaraan kegiatan pembelajaran semester genap 2019/2020 pada seluruh jenjang program pendidikan agar dapat disesuaikan dengan kebutuhan masing-masing perguruan tinggi sehingga seluruh kegiatan akademik dapat terlaksana dengan baik. 5. Persiapan pelaksanaan langkah-langkah sebagaimana disampaikan dalam angka 1 sampai 4 di atas agar terlebih dahulu dikoordinasikan dengan Lembaga Layanan Pendidikan Tinggi setempat.
Selain dari pemaparan diatas terjadinya peningkatan penderita COVID-19 di Indonesia yang terus meningkat setiap hari menandakan bahwa masih kurang tersosialisasinya informasi terkait dengan COVID-19. Selain itu permasalahan utama dari idenya pengabdian masyarakat ini adalah kurangnya pemahaman mahasiswiPGPAUD FIP UNESA angkatan 2019 terkait dengan pembuatan PPT kreatif yang sesuai untuk anak dini. Hal ini berdasarkan dari riview tugas PPT mata kuliah media dan sumber belajar yang ditempuh oleh mahasiswi semester ini. Untuk itu maka tim bekerjasama dengan HMJ PGPAUD angkatan 2019 untuk menyelenggarakan pelatihan ini.

\section{Permasalahan Mitra}

Adanya dampak wabah COVID-19 tersebut maka pelatihan ini bertujuan untuk mengatasi permasalahan sebagai berikut: 1. membantu pemerintah dalam mensosialisasikan informasi mengenai COVID-19 khususnya pada audiens anak melalui media sosial media khususnya youtube, 2. Mengatasi permasalahan kurang pemahamannya mahasiswi PGPAUD FIP UNESA angkatan 2019 terhadap kriteria power point untuk audiens anak. Hasil PowerPoint mahasiswi masih banyak yang kurang memperhatikan bentuk dan ukuran huruf, transisi slide sebelum dan sesudah, bentuk gambar, komposisi gambar, efek gerak huruf dan gambar, background, pemilihan warna, dan lain sebagainya). Oleh karena adanya pandemi ini maka kegiatan pengabdian masyarakat tidak dapat dilakukan secara langsung tatap muka sehingga kegiatan ini dilakukan melalui daring yaitu melalui group WhatApp.

Hasil dari pelatihan ini berupa PowerPoint terkait dengan COVID-19 dengan materi virus corona, cara menghindari terkena virus corona, apa yang anak dapat lakukan selama pandemi berlangsung. Selanjutnya hasil PowerPoint ini di unggah ke sosial media (youtube dengan channel pnesa unesa) dengan tujuan untuk menyebar luaskan informasi COVID-19 terutama untuk audiennya anak usia dini. Selain itu akan diperoleh data mengenai hasil posttest setelah kegiatan ini dilakukan.

\section{Solusi Permasalahan Mitra}

Solusi untuk kegiatan pengabdian dapat berlangsung dan menghasilkan output yang berguna untuk masyarakat luas pada umumnya. Antara lain solusi permsalahan mitra ini adalah; 1).hasil dari pelatihan ini berupa PPT kreatif 
berisi materi mengenai COVID 19 disebarluaskan melalui media sosial khususnya channel youtube pnesa unesa, 2).Hasil dari pelatihan ini akan diberikan kegiatan posttestmelalui google form dan di mana tehnik ini termasuk ke dalam kuantitatif deskriptif berbentuk survey. 3).Hasil survey berisikan pertanyaan-pertanyaan terkait dengan materi dan kepuasan peserta terhadap kegiatan pelatihan akan diolah datanya dan dijadikan artikel untuk disebarluaskan ke masyarakat luas.

\section{METODE PELAKSANAAN}

Pelatihan dilakukan pada tanggal 29 April 2020 hingga 6 Mei 2020 dengan daring menggunakan aplikasi WhatsApp.Sasaran pelatihan ini adalah 86mahasiswi PG PAUD angkatan 2019. Sebelum dilakukannya pelatihan ini kemampuan mahasiswi PGPAUD angkatan 2019 dalam membuat PPT teriview dari tugas PPT mata kuliah media dan sumber belajar. Terdapat $95,3 \%$ dari 86 mahasiswi yang belum paham mengenai PPT untuk audiens anak usia dini serta PPT yang bertujuan keranah pendidikan. Rata-rata para mahasiswi membuat PPT yang terdapat animasi bergerak, bentuk huruf yang berkelok-kelok, ukuran font yang kurang di perhatikan, perpaduan warna yang kurang di perhatikan, komposisi gambar yang tidak pas. Hal ini dapat terlihat pada hasil PPT bergerak bertema "TEMATIK" yang ada pada channel pnesa unesa.

Pada pelatihan PPT kreatif COVID-19 terdapat praktek langsung dan pemberian post test untuk melihat kemampuan mahasiswi sesudah mengikuti pelatihan. Materi yang diberikan pada post-test berupa materi terkait PPT kreatif untuk anak serta kepuasan mahasiswa terhadap kegiatan pelatihan. Selain itu hasil dari pelatihan ini dapat dilihat dari PPT kreatif mengenai COVID-19 yang di unggah di channel youtube pnesa unesa dan diberikan nilai .Berikut ini adalah tahapantahapan pelaksanaan kegiatan Pengabdian Masyarakat yang telah kami lakukan:

\section{Persiapan,}

Persiapan meliputi:

a. Memberi tahu HMJ PGPAUD angkatan 2019 dan penanggung jawab mata kuliah media dan sumber belajar baik kelas A dan kelas B mengenai akan diadakannya pelatihan pembuatan PowerPoint kreatif berbasis COVID-19 yang ditujukan pada anak usia dini

b. Menyusun materi pelatihan pembuatan PowerPoint kreatif berbasis COVID-19 yang sesuai dengan karakteristik anak usia dini

c. Membuat grup pada aplikasi WhatsApp yang akan digunakan untuk dalam pelatihan pembuatan PowerPoint kreatif berbasis COVID-19 yang ditujukan pada anak usia dini

\section{Diskusi}

Pelatihan dilaksanakan dengan model
dalam jaringan dengan menggunakan WhatsApp Group. Pada tahap diskusi ini diberikannya materi tentang cara pembuatan PowerPoint kreatif berbasis COVID-19 yang ditujukan kepada anak usia dini yaitu mengenai bentuk dan ukuran huruf, gambar, transisi, efek huruf dan gambar yang sesuai dengan karakteristik anak usia dini sehingga nantinya anak usia dini dapat dengan mudah memahami isi PowerPoint. Materi tersebut dishare kepada mahasiswi PG PAUD angkatan 2019 FIP Unesa menggunakan google form sebelum memulai diskusi. Hal tersebut untuk mengukur kepahaman mahasiswi sebelum diadakannya pelatihan pembuatan PowerPoint kreatif berbasis COVID-19 untuk anak usia dini

Pada tahap ini berlangsung selama tiga hari yaitu dua hari mahasiswi memberi respon terhadap materi pada google form yang telah dishare dan 1 hari proses diskusi pada WhatsApp Group

\section{Tanya Jawab}

Setalah proses diskusi maka dilakukan tanya jawab dengan tujuan untuk memberikan kesempatan kepada mahasiswi untuk bertanya mengenai apa yang belum dipahami.

\section{Pembimbingan Langsung dengan Daring}

Setalah dilakukannya diskusi dan tanya jawab maka mahasiswi praktek dalam pembuatan PowerPoint kreatif berbasis COVID-19 untuk anak usia dini. pada tahap ini dilukannya review kepada PowerPoint yang telah dibuat oleh mahasiswi dan memberikan apresiasi, kritikan dan saran. 


\section{HASIL DAN PEMBAHASAN}

Berdasarkan pelatihan daring tentang Pembuatan PowerPoint kreatif berbasis COVID-19 pada mahasiswi angkatan 2019 PG PAUD Fakultas Ilmu Pendidikan Universitas Negeri Surabaya maka dapat dijelaskan hasil dan pembahasannya sebagai berikut:

Pelatihan berlangsung pada tanggal 29 April 2020 hingga 6 Mei 2020 dengan daring meneggunakan aplikasi WhatsApp.Terdapat 86 responden yang mengikuti pelatihanpembuatan PowerPoint kreatif berbasis COVID-19 untuk anak usia dini yang merupakan mahasiswi PG PAUD Fakultas Ilmu Pendidikan Universitas Negeri Surabaya. Sebelum memasuki agenda pelatihan maka dilakukannya persiapan. Pada tahap persiapan ini memberi tahu mahasiswi angkatan 2019 mengenai akan diadakannya pelatihan pembuatan PowerPoint kreatif berbasis COVID-19 yang ditujukan pada anak usia dini, kemuadian menyusun materi dan menyiapkan contoh media PowerPoint yang sudah jadi sesuai dengan karakteristik anak dengan memberikan link video. Kemudian membuat grup pada aplikasi WhatsApp yang akan digunakan untuk dalam pelatihan pembuatan PowerPoint kreatif berbasis COVID-19 yang ditujukan pada anak usia dini. Berikut link video yang digunakan sebagai contoh media PowerPoint kreatif untk anak usia dini:

\section{https://forms.gle/BfNeaQoKXpxASST97,} https://youtu.be/1o2fZWTlva8

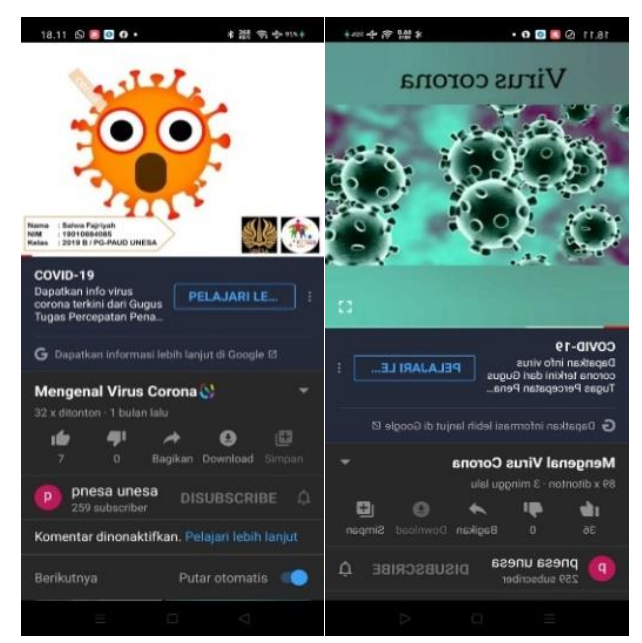

Gambar 1. Contoh PPT Covid-19

Setelah dilakukannya persiapan maka adanya agenda sebagai berikut (Tabel 1) :
Tabel 1. Agenda Pelatihan

\begin{tabular}{clll}
\hline No. & Metode & Tanggal & Instruktur \\
\hline 1. & Diskusi & 29 April & Sri \\
& & $2020-1$ & Widayati, \\
& & Mei & S.Pd.,M.P \\
& & 2020 & d \\
2. & Tanya Jawab & $2 \mathrm{Mei}$ & Sri \\
& & 2020 & Widayati, \\
& & & S.Pd.,M.P \\
3. & Bimbingan & $3-6$ & d \\
& Langsung & Mei & Widayati, \\
& & 2020 & S.Pd.,M.P \\
& & & d \\
\hline
\end{tabular}

Pada metode diskusi ini dilakukan dengan model dalam jaringan menggunakan WhatsApp Group.Pada tahap diskusi ini diberikannya materi kepada para peserta tentang cara pembuatan PowerPoint kreatif berbasis COVID-19 yang ditujukan kepada anak usia dini yaitu mengenai bentuk dan ukuran huruf, gambar, transisi, efek huruf dan gambar yang sesuai dengan karakteristik anak usia dini sehingga nantinya anak usia dini dapat dengan mudah memahami isi PowerPoint. Materi dishare kepada mahasiswi PG PAUD angkatan 2019 FIP dengan memberikan link contoh media PowerPoint yang sudah jadi dengan kesesuaian karakteristik anak, selain itu diberikan juga voice note yang menjelaskan tentang segala ketentuan yang perlu diperhatiakan dalam pembuatan media PowerPoint untuk anak usia dini dengan durasi 1 jam dalam satu hari yaitu pada jam 12.0013.00 WIB. Pada proses diskusi parapeserta memiliki antusias yang cukup baik dan 86 peserta menyimak dengan baik.

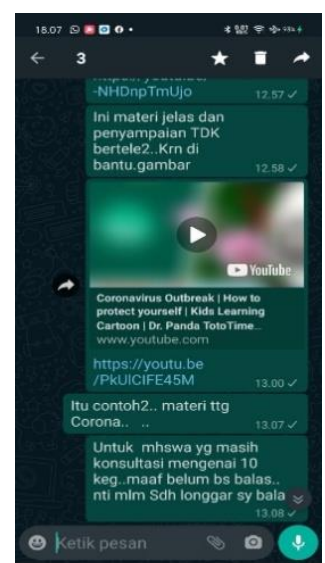

Gambar 2. Proses Diskusi pada WhatsApp Group 
Setelah metode diskusi maka dilanjutkan dengan metode tanya jawab. Tujuan dari metode ini adalah untuk memberikan kesempatan kepada mahasiswi bagi yang masih bingung dengan materi yang telah disampaikan pada metode diskusi. Pada tanggal 02 Mei 2020 metode tanya jawab dilakukan dengan durasi 1 jam yaitu pukul 12.00-13.00.

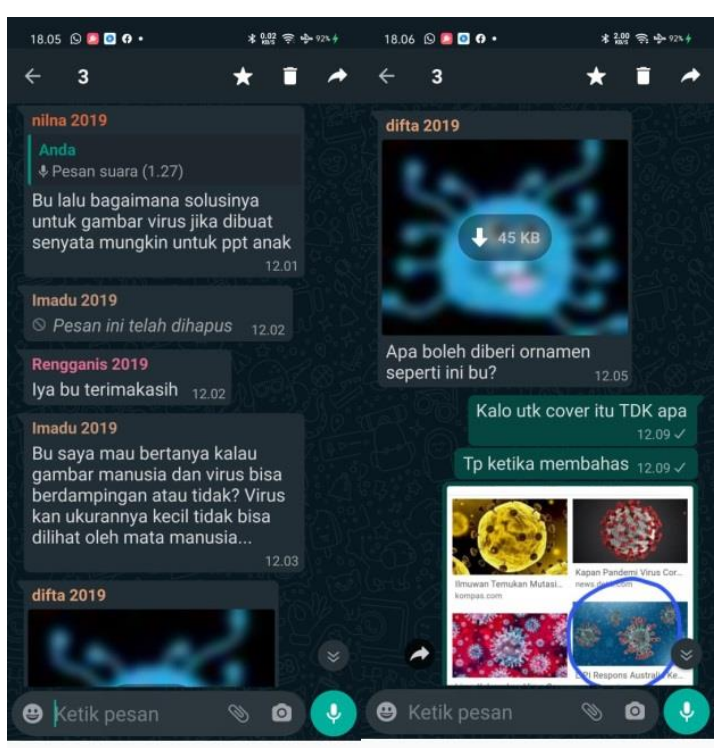

Gambar 3.Tanya Jawab pada WhatsApp Group

Rata-rata mahasiswi menanyakan mengenai material yang sesuai untuk dimasukkan kedalam PowerPoint seperti tingkat kekongritan gambar, font yang sesuai dan ukuran yang pas sehingga anak usia dini mudah memahami dan tertarik untuk menggunakan media PowerPoint tersebut.

Setelah metode tanya jawab, maka dilakukannya metode bimbingan langsung. Metode bimbangan langsung ini dilakukan selama 4 hari yaitu mahasiswi peraktik membuat media PowerPoint dengan bimbingan langsung pemateri. Ketika mahasiswi sudah selesai membuat media PowerPoint tentang COVID-19 mahasiswi dapat mengirimkan hasil medianya pada WhatsApp Group kemudian pemateri melakukan koreksi dan memberikan masukan yang sesuai dengan karakteristik media PowerPoint kreatif untuk anak usia dini. jika hasil media PowerPoint sudah sesuai dengan karakteristik media PowerPoint kreatif untuk anak usia dini maka mahasiswi tidak perlu memperbaiki dan diberikannya apresiasi dengan ucapan.
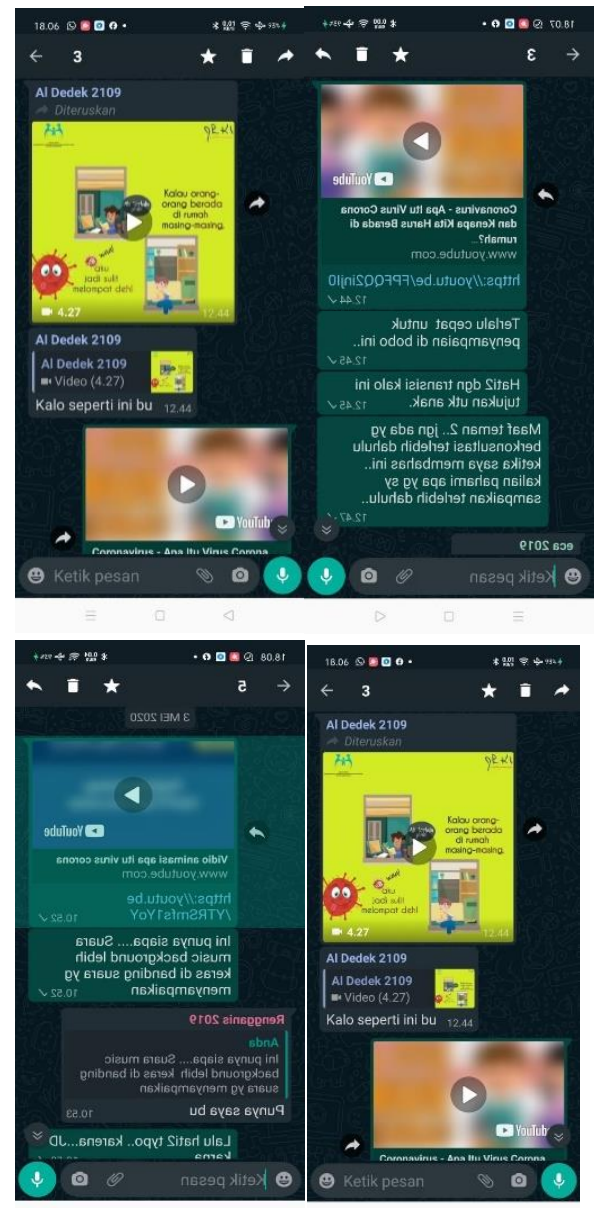

Gambar 4. Diskusi langsung pada WhatsApp Group

Setelah semua metode dilakukan, maka saatnya untuk membagikan google form yang telah dibuat untuk mengetahui tingkat pemahaman peserta terhadap materi dan tingkat kepuasan peserta terhadap pelatihan pembuatan media PowerPoint COVID-19 untuk anak usia dini yang telah dilakukan secara daring. Google form yang dibuat terdiri dari 10 instrumen review materi dan 5 instrumen untuk mengetahui kepuasan peserta terhadap pelatihan pembuatan media PowerPoint COVID-19 untuk anak usia dini. Google form tersebut telah diisi oleh seluruh peserta yaitu sebanyak 86 responden. Google form review materi dan kepuasan peserta berisi instrumen yang favorable sehingga apabila peserta menjawab sangat setuju atau setuju maka dapat dikatakan peserta telah memahami dan sepakat dengan kalimat atau materi. Berikut hasil dari google form review materi pelatihan pembuatan media PowerPoint COVID-19 untuk anak usia dini. 
Tabel 2.Hasil Review Materi

\begin{tabular}{lcc}
\hline \multicolumn{1}{c}{ Respons } & Frekuensi & $\%$ \\
\hline Sangat Setuju & 54 & $62,8 \%$ \\
Setuju & 28 & $32,5 \%$ \\
Tidak Setuju & 4 & $4,7 \%$ \\
$\begin{array}{l}\text { Sangat Tidak } \\
\text { Setuju } \\
\text { Total }\end{array}$ & 0 & $0 \%$ \\
\hline
\end{tabular}

Berdasarkan Tabel 2, dapat dijelaskan bahwa lebih dari $50 \%$ peserta telah sepakat dan memahami materi pelatihan pembuatan media PowerPoint COVID-19 untuk anak usia dini. materi yang dapat dijelaskan yaitu: 1) PPT anak usia dini haruslah tersusun materinya dari umum ke terperinci, 2) PPT untuk anak usia dini harus menggunakan bentuk dan ukuran huruf yang jelas (tidak boleh bentuk huruf yang meliuk-liuk, huruf sambung, huruf menggunakan ukiran, dan berbagai huruf yang jarang digunakan pada buku teks dan lingkungan sekitar anak), 3) PPT untuk anak usia dini harus menggunakan gambar yang jelas, se-konkrit mungkin, serta posisi kombinasi yang tepat dan sesuai, 4) PPT untuk anak usia dini harus menggunakan latar belakang yang sederhana, tidak banyak detail agar materi dapat tersampaikan dengan baik serta anak dapat total fokus pada materi, 5) PPT untuk anak usia dini ,gerak gambar dan gerak huruf harus di perhatikan, tidak boleh berlebihan. Jika berlebihan akan membuat anak lebih memperhatikan gambar/huruf yang bergerak dibandingkan menyimak materi, 6) PPT untuk anak usia dini, dalam pemilihan gambar untuk cover harus sesuai (berkaitan) dengan materi yang akan disampaikan, 7) Suara background musik dalam PPT untuk anak usia dini atau PPT untuk audiens lainnya, harus kecil suaranya dibandingkan dengan suara pemateri agar audiens bisa terfokus pada materi, 8) PPT untuk anak usia dini harus memperhatikan komposisi warna agar materi tampak jelas dan terbaca untuk anak, 9) PPT untuk anak usia dini harus memperhatikan transisi waktu antara slide sebelum dan sesudahnya. Transisi tidak boleh terlalu cepat,agar anak lebih lama dalam menyimak materi, 10) Penggunaan efek suara pada PPT untuk anak usia dini diupayakan berhubungan dengan materi serta untuk volumenya harus diperhatikan penempatan tinggi-rendahnya.

Selain itu dari hasil riview PPT kreatif COVID-19, diperoleh hasil kualitas PPT mahasiswi meningkat menjadi $100 \%$. Semua mahasiswi memperhatikan penggunaan gambar yang di ambil, komposisi, warna, suara latar belakang yang digunakan, ukuran huruf dan bentuk huruf agar anak dapat cepat dan jelas menerima informasi dari PPT kreatif COVID-19.

Tabel 3. Hasil Kepuasan Peserta

\begin{tabular}{|c|c|c|c|c|}
\hline Instrumen & SS & $\mathrm{S}$ & TS & STS \\
\hline $\begin{array}{l}\text { Materi mengenai } \\
\text { pembuatan PPT untuk } \\
\text { anak usia dini sangat } \\
\text { bermanfaat sekali bagi } \\
\text { saya. }\end{array}$ & 57 & 29 & - & - \\
\hline $\begin{array}{l}\text { Penjelasan materi } \\
\text { mengenai pembuatan } \\
\text { PPT untuk anak usia } \\
\text { dini yang diberikan } \\
\text { sudah jelas dan mudah } \\
\text { dipahami. }\end{array}$ & 32 & 54 & - & - \\
\hline $\begin{array}{l}\text { Contoh - contoh PPT } \\
\text { untuk anak usia dini } \\
\text { yang diberikan } \\
\text { membantu pemahaman } \\
\text { dan kejelasan } \\
\text { mengenai pembuatan } \\
\text { PPT untuk anak usia } \\
\text { dini yang baik dan } \\
\text { sesuai. }\end{array}$ & 30 & 56 & - & - \\
\hline $\begin{array}{l}\text { Materi mengenai } \\
\text { pembuatan PPT untuk } \\
\text { anak usia dini belum } \\
\text { pernah diberikan/ } \\
\text { disampaikan oleh } \\
\text { dosen lainnya. }\end{array}$ & 28 & 58 & - & - \\
\hline $\begin{array}{l}\text { Setelah mendapatkan } \\
\text { materi PPT untuk anak } \\
\text { usia dini, hasil PPT } \\
\text { yang saya buat menjadi } \\
\text { lebih baik dan bagus } \\
\text { hasilnya. }\end{array}$ & 45 & 41 & - & - \\
\hline
\end{tabular}

Berdasarkan hasil pada Tabel 3 dapat dijelaskan bahwa respon dominan dari responden adalah sangat setuju kemudian setuju dan tidak ada yang memberi respon tidak setuju dan Sangat tidak setuju. Hal tersebut berarti responden memiliki rasa kepuasan terhadap pelatihan pembuatan PowerPoint COVID-19 untuk anak usia dini maka dapat 
dinyatakan pelatihan pembuatan PowerPoint COVID-19 untuk anak usia dini dapat meningkatkan kefahaman dan kemampuan mahasiswi PG PAUD Fakultas Ilmu Pendidikan Universitas Negeri Surabaya dalam membuatan media PowerPoint COVID-19 untuk anak usia dini serta menghasilkan PPT yang kreatif.

\section{SIMPULAN DAN SARAN}

Berdasarkan hasil pelatihan yang telah dilakukan dengan model daring menggunakan WhatsApp group maka dapat disimpulkan bahwa 1) Sebelum dilakukanpelatihan, mahasiswi PG PAUD angkatan 2019 memiliki kemampuan yang kurang dalam pembuatan PowerPoint. Hal ini terlihat dari hasil riview tugas membuat PPT “TEMATIK” untuk anak usia dini, masih banyak mahasiswi yang menggunakan font, animasi dan efek yang tidak sesuai dengan karakteristik anak, suara latar belakang yang lebih keras dari pemateri sehingga dapat diasumsikan dapat membuat anak bingung dan tidak memahami isi PowerPoint. 2) Setelah dilakukannya pelatihan selama satu minggu yang terdiri dari proses persiapan, diskusi, tanya jawab dan bimbingan langsung dengan daring maka mahasiswi mampu membuat PowerPoint yang lebih baik yang sesuai dengan karakteristik anak usia dini yang nantinya dapat dengan mudah dipahami oleh anak usia dini.

Berdasarkan hasil pelatihan yang dilakukan maka dapat diberikan saran kepada 1)
Mahasiswi PG PAUD atau calon pendidik PAUD untuk memahami dan memiliki kemampuan untuk membuat media untuk anak usia dini sesuai dengan karakteristsik anak usia dini. 2) Pembaca, diharapkan dapat menjadikan pelatihan ini sebagai acuan untuk melakukan pelatihan yang relavan

\section{UCAPAN TERIMA KASIH}

Pengabdian Masyarakat Ini Didukung Oleh Prodi PG PAUD Fakultas Ilmu Pendidikan Universitas Negeri Surabaya

\section{DAFTAR PUSTAKA}

Branch, R. M. (2009). Instructional DesignThe ADDIE Approach.New York:Springer

Hasyim, Hasanah. (2016). Teknik Teknik Observasi (Sebuah Alternatif Metode Pengumpulan Data Kualitatif Ilmu Sosial). Jurnal Al-Taqaddum, vol.8, no.1, Universitas Islam Negeri Semarang.

Riduwan. (2013).Skala Pengukuran Variabel-variabel Pengabdian Bandung: Alfabeta

Sukardi. (2003). Metode Pengabdian Pendidikan. Jakarta: Bumi Aksara 